\title{
Kebiasaan makanan belangkas, Tachypleus gigas (Müller, 1785) dan Carcinoscorpius rotundicauda (Latreille, 1802) di perairan pesisir Balikpapan, Kalimantan Timur
}

\author{
Food habit of horseshoe crabs, Tachypleus gigas (Müller, 1785) and Carcinoscorpius \\ rotundicauda (Latreille, 1802) in Balikpapan coastal waters, East Kalimantan
}

\author{
Rani Nuraisaha, Naila K. Aini ${ }^{\mathrm{a}}$, Ali Mashar ${ }^{\mathrm{b}}$, Zairion Zairion ${ }^{\mathrm{b}}$, Yuni P. Hastutic ${ }^{\mathrm{c}}$, Peter Funch ${ }^{\mathrm{d}}$, Yusli Wardiatno ${ }^{\text {bef }}$ \\ aProgram Studi Pengelolaan Sumberdaya Perairan, Sekolah Pascasarjana, Institut Pertanian Bogor, Kampus IPB Dramaga Bogor, \\ 16680, Indonesia [+6281322280429] \\ bDepartemen Sumberdaya Perairan, Fakultas Perikanan dan Ilmu Kelautan, Institut Pertanian Bogor, Kampus IPB Dramaga Bogor, \\ 16680, Indonesia \\ 'Departemen Budidaya Perairan, Fakultas Perikanan dan Ilmu Kelautan, Institut Pertanian Bogor, Kampus IPB Dramaga Bogor, \\ 16680 , Indonesia \\ ${ }^{\mathrm{d} D e p a r t e m e n ~ B i o l o g i ~-~ G e n e t i k, ~ E k o l o g i ~ d a n ~ E v o l u s i, ~ U n i v e r s i t a s ~ A a r h u s, ~ D e n m a r k ~}$ \\ ePusat Penelitian Lingkungan Hidup, Lembaga Penelitian dan Pengabdian kepada Masyarakat, Institut Pertanian Bogor, Kampus IPB \\ Darmaga Bogor, 16680, Indonesia \\ fPusat Kajian Sumberdaya Pesisir dan Lautan, Institut Pertanian Bogor, Kampus IPB Baranangsiang Bogor, 16143, Indonesia
}

\section{Article Info:}

Received: 08 - 04 - 2020

Accepted: 29 - 04 - 2020

\section{Keywords:}

Food niche breadth, Index of preponderance, Limulidae, niche overlap

\section{Corresponding Author:}

Yusli Wardiatno

Departemen Manajemen

Sumberdaya Perairan, Fakultas

Perikanan dan Ilmu Kelautan,

Institut Pertanian Bogor;

Tel. +628128608966

Email:

yusli@apps.ipb.ac.id

\begin{abstract}
Horseshoe crabs are living fossils found in Indonesia. This study examined the food habit of horseshoe crabs (Carcinoscorpius rotundicauda and Tachypleus gigas) collected from Balikpapan coastal waters, East Kalimantan. Horseshoe crabs were captured using gill nets and picked by hand along the Balikpapan coast. The width of the prosoma and the body weight of each individual were measured, and the gut contents were analysed to determine the preponderance index, food niche breadth, and niche overlap. Carcinoscorpius rotundicauda prosoma widths ranged from 4.1 to $15.4 \mathrm{~cm}$ and those of Tachypleus gigas ranged from 2.8 to $24 \mathrm{~cm}$. Eight food items were found in the gut of the horseshoe crabs, namely: bivalves, gastropods, scaphopoda, polychaetes, echinoderms, crustaceans, leaf litter and others. Based on the preponderance index, gastropods were the main food item of the two horseshoe crab species. In accordance to the food composition the horseshoe crabs inhabiting Balikpapan coastal waters are categorized as benthivores.
\end{abstract}

How to cite (CSE Style $8^{\text {th }}$ Edition):

Nuraisah R, Aini NK, Mashar A, Zairion Z, Hastuti YP, Funch P, Wardiatno Y. 2020. Kebiasaan makanan belangkas, Tachypleus gigas (Müller, 1785) dan Carcinoscorpius rotundicauda (Latreille, 1802) di perairan pesisir Balikpapan, Kalimantan Timur. JPSL 10(2): 153-162. http://dx.doi.org/10.29244/jpsl.10.2.153-162.

\section{PENDAHULUAN}

Belangkas merupakan salah satu living fossil yang ada hingga saat ini, hal ini dikarenakan belangkas dapat mempertahankan morfologi mereka yang hampir tidak berubah untuk 150 juta tahun terakhir (Zhu et al., 2020). Terdapat empat jenis belangkas yang ada di dunia. Tiga diantaranya berada di Indonesia, Tachypleus tridentatus (Leach, 1819), Tachypleus gigas (Müller, 1785), Carcinoscorpius rotundicauda (Latreille, 1802), yang disebut juga dengan Asian horseshoe crab dan Limulus polyphemus (Linnaeus, 1758) yang disebut 
Atlantic horseshoe crab. Asian horseshoe crab terdistribusi dimulai dari perairan India, China, Indonesia, Malaysia hingga Jepang (Chatterji et al., 1992; Tsuchiya, 2009; Cartwright-Taylor et al., 2011; Zaleha et al., 2012; Razak et al., 2017; Jawahir et al., 2017; Mashar et al., 2017; John et al., 2018a, b). Atlantic horseshoe $c r a b$ terdistribusi dari Pulau Dauphin, Alabama hingga ke Maine, United State of America dan di Teluk Delaware (Carmichael et al., 2004; Chabot dan Watson, 2010; Smith et al., 2013; Zhu et al., 2020).

Belangkas merupakan komponen penting komunitas makrobentos pada perairan pesisir dengan substrat berpasir halus atau berlumpur. Menurut Manca et al. (2016), belangkas dapat ditemukan di area estuari dan pantai selama musim non monsoon (spawning season). Karakteristik lingkungan estuari yang membuat berbagai spesies flora dan fauna mangrove dapat berkembang biak dengan baik di wilayah ini (Nugroho et al., 2018). Sebuah studi yang dilakukan oleh Watson dan Chabot (2010), menemukan bahwa mereka menetap di laut dalam secara pasif dengan mengubur diri dengan pasir selama monsoon (non-spawning season).

Belangkas memiliki peran penting secara ekologi dan ekonomi. Secara ekologi belangkas berperan sebagai bioturbator dan mengendalikan hewan bentik (Smith, 2007; John et al., 2012b). Selain itu, belangkas memiliki peran sebagai penyeimbang rantai makanan dan sebagai sumber protein bagi beberapa spesies burung pantai (Beekey et al., 2013). Belangkas dewasa merupakan omnivora (Botton, 2009). Sebagai hewan bentik (Carmichael et al., 2004), seleksi mangsa telah diidentifikasi sebagai kebiasaan belangkas selama mencari makanan (Botton, 1984; Chatterji et al., 1992). Seleksi makanan cenderung mengarah ke komunitas bentik, bivalvia, polychaeta, krustase, gastropod, dan makrofita (Botton dan Haskin, 1984; Walls et al., 2002; Botton et al., 2003; Razak, 2017). Penelitian Botton (1984) dan John et al., (2012a), mendukung asumsi dimana perbedaan pada seleksi makanan pada belangkas terhadap ketersediaan makanan antara musim dan area geografis. John et al. (2012a) menyatakan bahwa polychaeta merupakan makanan yang paling disukai oleh $C$. rotundicauda yang berhabitat di Semenanjung Malaysia. Mekanisme mangsa ditangkap oleh belangkas menggunakan chelate walking legs (Sekiguchi dan Shuster, 2009). Botton dan Haskin (1984), cara belangkas memakan kerang dengan merusak cangkang kerang menggunakan pincer tipped walking leg atau chelicerae. Secara ekonomi belangkas dimanfaatkan telurnya untuk dikonsumsi manusia (Eidman et al., 1997; Shin et al., 2009) dan darahnya dimanfaatkan di bidang industri farmasi sebagai pendeteksi endotoksin pada darah manusia dan pengujian obat bebas dari patogen (Novitsky, 1994; John et al., 2012b).

Perairan pesisir Indonesia merupakan salah satu habitat penting bagi belangkas di dunia. Tiga dari empat spesies belangkas di dunia dapat ditemukan di wilayah pesisir Indonesia. Belangkas merupakan salah satu hewan yang dilindungi dalam Peraturan Menteri Lingkungan Hidup dan Kehutanan No. 20 Tahun 2018 tentang jenis tumbuhan dan satwa yang dilindungi. Meskipun wilayah Pesisir Indonesia adalah wilayah distribusi belangkas, informasi ilmiah mengenai jenis belangkas terbatas. Beberapa penelitian mengenai belangkas di Indonesia telah dilakukan, diantaranya mengenai sebaran habitatnya (Mashar et al., 2017; Erwyansyah et al., 2018; John et al., 2018a, b), morfometri (Meilana, 2016; Sumarmin et al., 2017), kepastian spesies dengan pendekatan molekular (Erwyansyah et al., 2018), biologi reproduksi (Eidman et al., 1997), dan keragaman genetik (Aini et al., 2020).

Berdasarkan potensi manfaat, pengelolaan yang telah dilakukan serta keterbatasan data belangkas di Indonesia khususnya mengenai potensi makanan belangkas, maka dilaksanakan penelitian terhadap potensi makanan belangkas dengan menganalisis isi perut belangkas. Hal ini diharapkan dapat menjadi landasan dalam penetapan tempat konservasi bagi spesies belangkas di perairan pesisir Balikpapan, Kalimantan Timur sehingga keberadaan belangkas dapat tetap terjaga dan tidak punah. 


\section{METODE}

\section{Lokasi dan Waktu Penelitian}

Penelitian ini dilaksanakan di perairan pesisir Balikpapan, Kalimantan Timur (Gambar 1). Lokasi penelitian merupakan lokasi hutan mangrove yang masih memiliki kondisi baik. Penelitian dilaksanakan pada bulan Oktober-November 2019. Pengamatan isi perut contoh belangkas dilaksanakan di Laboratorium Biologi Makro, Departemen Manajemen Sumberdaya Perairan, Fakultas Perikanan dan Ilmu Kelautan, Institut Pertanian Bogor.

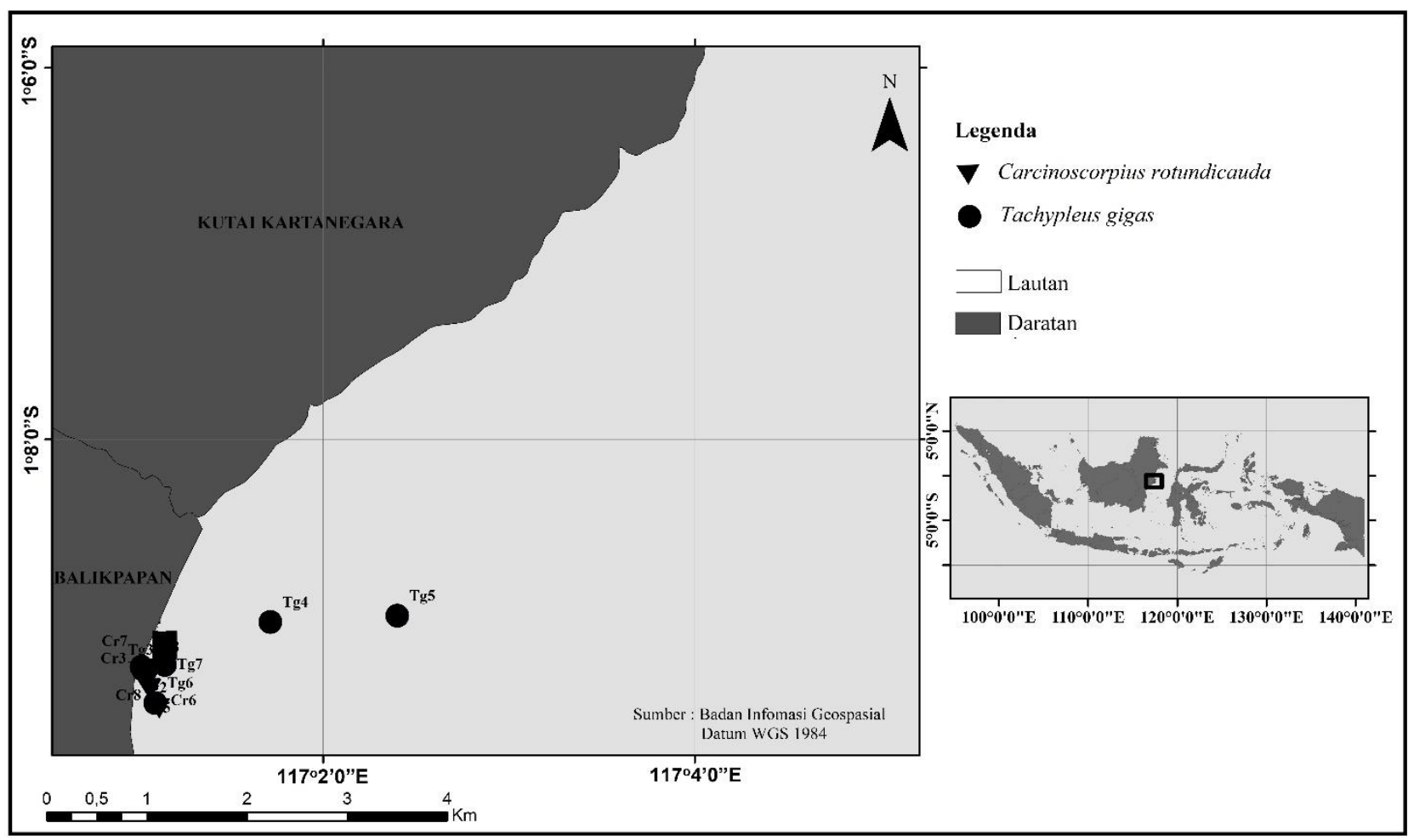

Gambar 1 Lokasi pengambilan contoh belangkas (Tachypleus gigas dan Carcinoscorpius rotundicauda) di perairan pesisir Balikpapan, Kalimantan Timur

\section{Metode Pengumpulan Data}

Metode pengumpulan data dilakukan secara acak sederhana dengan dibantu oleh nelayan setempat menggunakan alat tangkap berupa jaring insang (ukuran mata jaring 4 inchi) dan pengambilan langsung menggunakan tangan di sepanjang pesisir pantai. Pemasangan jaring insang dilakukan pada sore hari, dibiarkan semalam, dan diangkat pada pagi hari berikutnya, sedangkan pengambilan langsung dengan tangan dilakukan pada pagi hari saat air laut surut. Belangkas yang tertangkap langsung dilakukan pencatatan jenis kelamin, pengukuran lebar prosoma, dan bobot. Mengikuti kode etik, belangkas contoh dimatikan menggunakan es sebelum dilakukan pembedahan (Chatterji et al., 1992; Razak et al., 2017). Karapas dibuka secara ventral dari daerah ventral posterior disepanjang tepi prosoma dan berlanjut di bawah insang ke ujung anterior karapas opisthoma yang menutupi sendi telson. Isi perut yang sudah dikeluarkan, dipindahkan ke dalam plastik contoh dan diawetkan menggunakan formalin 4\% untuk kemudian dianalisis di Laboratorium Biologi Makro, Departemen Manajemen Sumberdaya Perairan, Fakultas Perikanan dan Ilmu Kelautan, Institut Pertanian Bogor. Lambung dibedah, dikeluarkan isinya dan ditaruh di cawan petri. Organisme yang terdapat di lambung diidentifikasi ke dalam group, yaitu bivalvia, gastropoda, scaphopoda, krustase, polychaeta, echinodermata dan lain-lain, sesuai dengan kriteria yang dibuat oleh Squires dan Dawe (2003). 


\section{Metode Analisis Data}

Analisis kebiasaan makanan dilakukan menggunakan indeks bagian terbesar (Index of Preponderance) (Natarajan dan Jhingram, 1961):

Keterangan:

$$
\mathrm{IP}=\frac{\mathrm{Oi} \times \mathrm{Vi}}{\sum \mathrm{Oi} \mathrm{xVi}} \times 100
$$

IP = Index of preponderance (indeks bagian terbesar)

$\mathrm{Vi}=$ persentase volume jenis makanan ke $\mathrm{i}$

Oi $=$ frekuensi kejadian jenis makanan ke $\mathrm{i}$

Nilai indeks bagian terbesar (IP) berkisar antara (Nikolsky, 1963):

$>25 \%$ = pakan utama

$4-25 \%$ = pakan pelengkap

$<4 \% \quad=$ pakan tambahan

Luas relung makanan digunakan untuk menentukan keragaman makanan yang dimakan oleh belangkas, menurut Levins (1968) dengan persamaan sebagai berikut:

Keterangan:

$$
\mathrm{Bi}=\frac{1}{\sum \mathrm{Pij}^{2}}
$$

$\mathrm{Bi}=$ luas relung makanan

$\mathrm{P}_{\mathrm{ij}}{ }^{2}=$ proporsi organisme makanan yang dimanfaatkan oleh jenis belangkas $\mathrm{j}$

Hulbert (1978) menyatakan bahwa pembakuan nilai luas relung makanan supaya nilai 0-1 dihitung dengan rumus sebagai berikut:

Keterangan:

$$
\mathrm{Ba}=\frac{\mathrm{Bi}-1}{\mathrm{n}-1}
$$

$\mathrm{Ba}=$ luas relung makanan yang dibakukan

$\mathrm{Bi}=$ luas relung makanan Levins

$\mathrm{n} \quad=$ jumlah organisme makanan yang potensial untuk dimanfaatkan

Nilai Ba bervariasi dari 0 (spesies mengkonsumsi satu jenis makanan) sampai 1 (spesies mengeksploitasi jenis makanan yang tersedia dalam proporsi yang sama). Nilai luas relung (Ba) diklasifikasikan sebagai berikut: tinggi (>0.6), sedang (0.4-0.6), dan rendah $(<0.4)$ (Novakowski et al., 2008)

Tumpang tindih relung makanan digunakan untuk menghitung tingkat kesamaan makanan antara spesies belangkas dalam famili Limulidae dengan rumus Simplified Morista Index of overlap (Horn, 1966) sebagai berikut:

Keterangan:

$$
\mathrm{C}_{\mathrm{H}}=\frac{2 \sum_{i}^{n} P_{i j} \times P_{i k}}{\sum_{i}^{n} P_{i j}^{2}+P_{i k}^{2}}
$$

$\mathrm{C}_{\mathrm{H}}=$ indeks Morisita yang disederhanakan

$\mathrm{P}_{\mathrm{ij}} \quad=$ proporsi organisme makanan ke $\mathrm{i}$ yang dimanfaatkan oleh jenis ikan $\mathrm{j}$

$\mathrm{P}_{\mathrm{ik}}=$ proporsi organisme makanan ke i yang dimanfaatkan oleh jenis ikan $\mathrm{k}$

$\mathrm{n} \quad=$ jumlah organisme makanan 


\section{HASIL DAN PEMBAHASAN}

\section{Komposisi dan Jenis Makanan}

Hasil tangkapan belangkas di Pesisir Balikpapan sebanyak 65 ekor $C$. rotundicauda dan 68 ekor $T$. gigas dengan lebar prosoma masing-masing berkisar antara 4.1-15.4 cm dan 2.8-24 cm. Isi lambung yang dianalisis berasal dari lambung yang utuh dan terdapat makanan di dalamnya, berjumlah 8 ekor untuk $C$. rotundicauda dan 12 ekor untuk $T$. gigas. Jenis-jenis makanan belangkas yang teridentifikasi dari 20 lambung dikelompokan menjadi 8 kelompok selama masa penelitian (Tabel 1). Semua kelompok makanan termasuk dalam kategori organisme bentik, hal ini dikarenakan belangkas merupakan organisme bentik dengan karakteristik posisi mulut berada di bawah.

Tabel 1 Kelompok makanan pada isi lambung belangkas (C. rotundicauda dan T. gigas)

\begin{tabular}{cll}
\hline No & Kelompok Makanan & \\
\hline 1 & Bivalvia & $\begin{array}{l}\text { Potongan cangkang kerang berwarna putih kusam, sangat jarang } \\
\text { cangkang yang utuh; terutama Tellina } \text { sp., Meretrix } \text { sp. }\end{array}$ \\
& & $\begin{array}{l}\text { Potongan cangkang berbentuk helica coil; Turritellidae, Eglisia } \text { sp., } \\
\text { Turridae. }\end{array}$ \\
& Gastropoda & $\begin{array}{l}\text { Potongan cangkang terbuka kedua ujungnya, berbentuk silinder, } \\
\text { berwarna putih }\end{array}$ \\
3 & Scaphopoda & Potongan cangkang kitin, sebagian besar amphipoda tetapi juga \\
& & copepoda dan krustase lainnya \\
4 & Krustase & Potongan chaeta \\
5 & Polychaeta & Bahan organik berwarna gelap \\
6 & Serasah & Potongan timun laut \\
7 & Echinodermata & Foraminifera, makrofita, jaringan ikan \\
8 & Lain-lain &
\end{tabular}

Komposisi jenis makanan pada isi lambung belangkas hampir sama antara $C$. rotundicauda dan T. gigas. C. rotundicauda memiliki komposisi jenis makanan yang lebih beragam dibandingkan dengan $T$. gigas. Secara khusus pada penelitian ini, C. rotundicauda mengkonsumsi bivalvia, gastropoda, scaphopoda, polychaeta, echinodermata, serasah dan lain-lain, sedangkan T. gigas mengkonsumsi bivalvia, gastropoda, scaphopoda, serasah dan lain-lain.

Hasil penelitian John et al. (2012a) di Pahang, Malaysia mengemukakan bahwa belangkas $C$. rotundicauda mengkonsumsi bivalvia, gastropoda, polychaeta dan lain-lain (foraminifera, yuwana ikan, larva serangga, amfipod dan isopod). Hasil yang hampir sama dikemukakan oleh Zhou dan Morton (2004) yang melakukan pengamatan isi lambung C. rotundicauda di Pesisir Hongkong. Chatterji et al., (1992) di India dan Razak et al. (2017) melaporkan isi lambung T. gigas, yaitu bivalvia, gastropoda, polychaeta, insekta, krustase, oligochaeta, echinodermata, makrofita dan lain-lain di Semenanjung Malaysia. Beberapa penelitian yang mengemukakan bahwa belangkas merupakan organisme yang selektif terhadap makanan (Chatterji et al., 1992; John et al., 2012a; Razak et al., 2017) tetapi terkadang menjadi pemakan yang mudah beradaptasi (John et al., 2012a). Isi perut belangkas sangat dipengaruhi oleh kelimpahan dan ketersediaan makanan di lingkungannya (Kwan et al., 2015; Razak et al., 2017).

Urutan makanan dapat dibedakan dalam tiga kategori, yaitu makanan utama, pelengkap dan tambahan (Nikolsky, 1963). Batasan untuk mengkategorikan jenis makanan berdasarkan nilai Indeks bagian terbesar (IP). Indeks bagian terbesar (IP) belangkas $C$. rotundicauda terdapat pada Gambar 2. Kelompok gastropoda menempati porsi yang terbesar (35.80\%), disusul serasah (29.32\%), lain-lain (21.60\%), scaphopoda (6.79\%), bivalvia (3.70\%), krustase (1.23\%), echinodermata (1.23\%) dan polychaeta $(0.31 \%)$. Kondisi ini memberikan gambaran bahwa gastropoda dan serasah merupakan makanan utama atau makanan yang paling disukai oleh belangkas jenis $C$. rotundicauda di Pesisir Balikpapan selama waktu penelitian. 
John et al. (2012a) melaporkan C. rotundicauda di Pahang, Malaysia lebih menyukai gastropoda dibandingkan dengan bivalvia dan gastropoda merupakan makanan yang paling umum ditemui di dalam perutnya. Nilai yang besar untuk gastropoda dapat diduga karena kelimpahan mereka lebih tinggi di habitatnya dibandingkan dengan komunitas makrobentik lainnya (Samidurai et al., 2011).

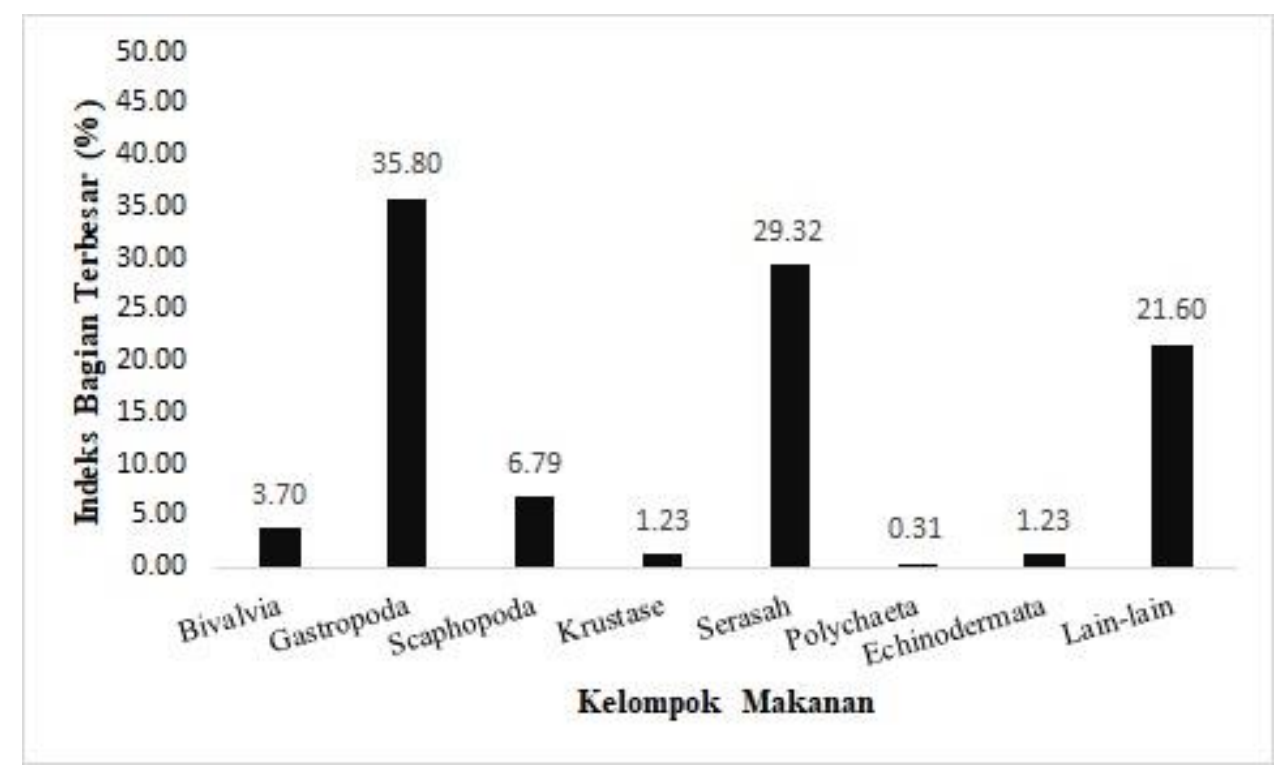

Gambar 2 Indeks bagian terbesar (IP) Carcinoscorpius rotundicauda berdasarkan contoh isi lambung selama penelitian di perairan pesisir Balikpapan, Kalimantan Timur

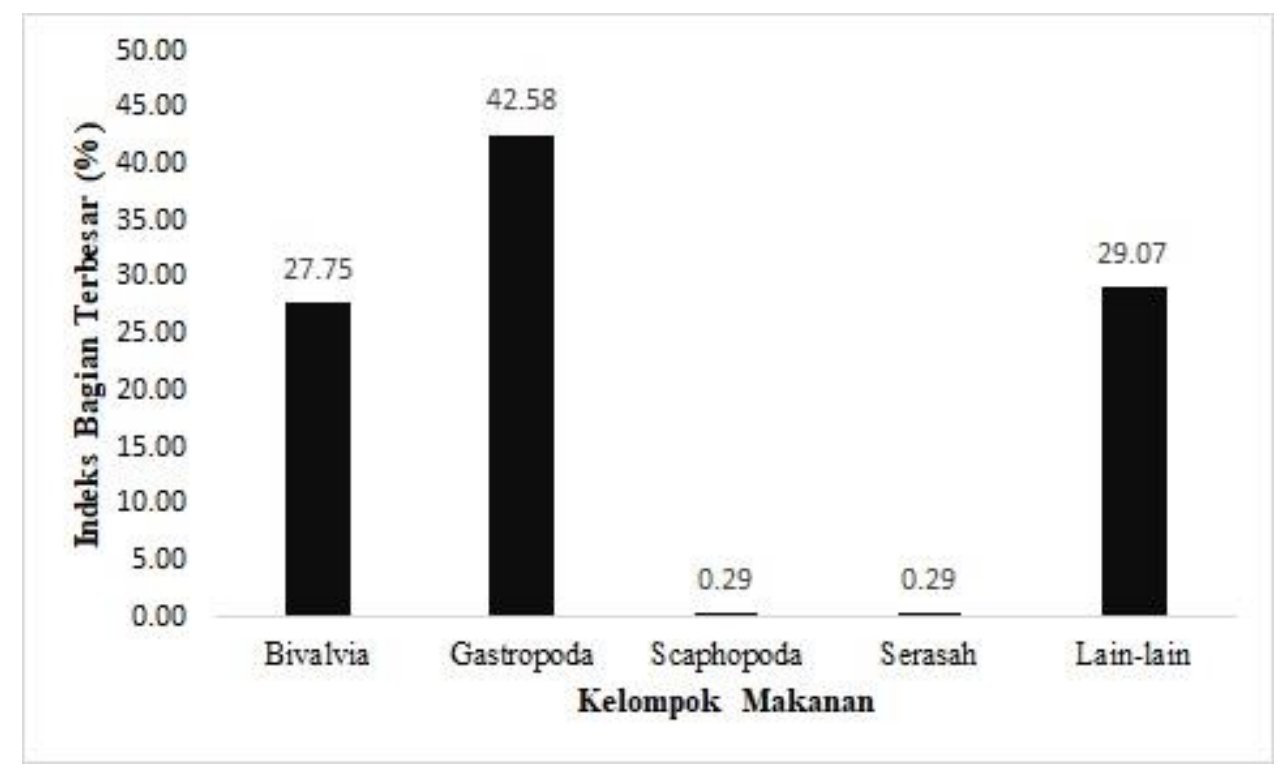

Gambar 3 Indeks bagian terbesar (IP) Tachypleus gigas berdasarkan contoh isi lambung selama penelitian di perairan pesisir Balikpapan, Kalimantan Timur

Spektrum komposisi makanan berdasarkan indeks bagian terbesar (IP) belangkas $T$. gigas terdapat pada Gambar 3. Kelompok gastropoda menempati porsi yang terbesar (42.58\%), disusul lain-lain (29.07\%), bivalvia (27.75\%), scaphopoda dan serasah (6.79\%). Kondisi ini memberikan gambaran bahwa gastropoda dan bivalvia merupakan makanan utama atau makanan yang paling disukai oleh belangkas jenis T. gigas di Pesisir Balikpapan selama waktu penelitian. 
Selain itu, gastropoda banyak tersedia di lingkungan sekitar ditemukannya contoh $T$. gigas. Hasil yang yang berbeda pada penelitian Chatterji et al. (1992) di India dan Razak et al. (2017) di Semenanjung Malaysia, $T$. gigas lebih menyukai bivalvia dibandingkan dengan gastropoda. Selain T. gigas yang lebih menyukai bivalvia, Walls et al. (2002) melaporkan jenis belangkas L. polyphemus juga lebih menyukai bilvavia. Kebiasaan makanan $L$. polyphemus yang ditangkap disepanjang paparan benua antara Carolina Utara dan New Jersey memperlihatkan bahwa moluska mendominasi sebanyak 87\% dari total diet (Botton dan Ropes, 1989).

\section{Luas Relung Makanan Dan Tumpang Tindih Relung Makanan}

Kapasitas belangkas dalam memanfaatkan makanan alami yang tersedia secara maksimal dapat terlihat dari luas relung. Luas relung makanan juga dapat menunjukkan selektivitas belangkas selama penelitian di Pesisir Balikpapan (Tabel 2). Nilai luas relung makanan C. rotundicauda (4.72) lebih besar dibandingkan dengan luas relung T. gigas (2.69). Hal ini mengindikasikan bahwa $C$. rotundicauda lebih mampu memanfaatkan beragam sumberdaya makanan di alam dengan baik dibandingkan $T$. gigas. Luas relung makanan bernilai rendah menunjukkan bahwa spesies tersebut selektif terhadap sumberdaya makanan di lingkungannya, sebaliknya jika bernilai besar menunjukkan keberagaman jenis makanan yang dikonsumsi (Colwell dan Futuyma, 1971; Levins, 1968). Pada penelitian ini C. rotundicauda mengkonsumsi makanan yang lebih beragam, sedangkan T. gigas lebih selektif dalam mengkonsumsi makanan. Nilai luas relung makanan yang dibakukan (Ba) pada Tabel 2 yang mendekati nol, menunjukkan bahwa spesies tersebut memiliki pola makan yang lebih sempit dan lebih terspesialisasi (Papacostas dan Freestone, 2016).

Tabel 2 Nilai luas relung makanan belangkas Carcinoscorpius rotundicauda dan Tachypleus gigas selama penelitian di perairan pesisir Balikpapan

\begin{tabular}{lcc}
\hline \multicolumn{1}{c}{ Spesies } & $\mathrm{Bi}$ & $\mathrm{Ba}$ \\
\hline Carcinoscorpius rotundicauda & 4.72 & 0.53 \\
Tachypleus gigas & 2.69 & 0.15 \\
\hline
\end{tabular}

Tumpang tindih relung (niche overlap) makanan adalah daerah ruang relung yang dihuni oleh dua penghuni relung atau lebih (Pianka, 1973). Menganalisa nilai tumpang tindih relung makanan merupakan suatu cara melihat seberapa banyak kesamaan jenis makanan yag dimanfaatkan oleh dua atau lebih spesies. Hal ini dapat menggambarkan kompetisi antar organisme dalam suatu ekosistem. Apabila nilai tumpang tindih yang diperoleh mendekati satu maka kedua spesies yang dibandingkan mempunyai jenis makanan yang hampir sama. Sebaliknya, apabila nilai tumpang tindih relung makanan mendekati nol berarti tidak ada jenis makanan yang sama antar spesies yang dibandingkan (Colwell dan Futuyma, 1971). Kedua spesies belangkas pada penelitian ini memiliki jenis makanan yang agak berbeda dikarenakan nilai tumpang tindih relung makanan antarspesies mendekati nol (Tabel 3). Peluang kompetisi yang tinggi dalam memanfaatkan makanan dapat dilihat dari ketertarikan dominan terhadap salah satu jenis makanan yaitu gastropod sebagai makanan utama (Gambar 2 dan Gambar 3). Belangkas yang memiliki nilai tumpang tindih rendah dapat digunakan untuk keperluan pengkayaan stok karena tidak berkompetisi dalam pemanfaatan makanan terhadap jenis lainnya yang terdapat dihabitat alaminya (Wijaya et al., 2017).

Tabel 3 Nilai tumpang tindih relung makanan antara Carcinoscorpius rotundicauda dan Tachypleus gigas selama penelitian di perairan pesisir Balikpapan, Kalimantan Timur

\begin{tabular}{lcc}
\hline \multirow{2}{*}{ Spesies } & \multicolumn{2}{c}{ Tumpang Tindih Makanan } \\
\cline { 2 - 3 } & Carcinoscorpius rotundicauda & Tachypleus gigas \\
\hline Carcinoscorpius rotundicauda & 1 & 0.28 \\
Tachypleus gigas & & 1 \\
\hline
\end{tabular}




\section{KESIMPULAN}

Belangkas $C$. rotundicauda dan $T$. gigas merupakan bentikvora berdasarkan jenis makanan yang ditemukan di dalam perutnya. Nilai indeks bagian terbesar (IP) menunjukkan bahwa gastropod merupakan makanan utama dari kedua jenis belangkas. Luas relung $C$. rotundicauda lebih lebar dibandingkan dengan $T$. gigas. Tumpang tindih relung rendah mengindikasikan rendahnya kompetisi antar kedua jenis belangkas.

\section{UCAPAN TERIMA KASIH}

Penelitian ini didanai oleh Pusat Penelitian Oseanografi, Lembaga Ilmu Pengetahuan Indonesia (PPO-LIPI) melalui Demand-Driven Research Fund (DDRF) No. B-5063/IPK.2/KS.02/III/2019 untuk YW dan IPB melalui skema PMDSU No. 6623/IT3.L1/PN/2019 ke YW (mengikuti kontrak antara Universitas IPB dan Kementerian Riset, Teknologi, dan Pendidikan Tinggi No. 261/SP2H/LT/DRPM/ 2019). Para penulis ingin mengucapkan terima kasih kepada mereka yang membantu dalam pengumpulan sampel dan pekerjaan laboratorium: Heri Seputro dan Ananingtyas Septia Darmarini.

\section{DAFTAR PUSTAKA}

Aini NK, Mashar A, Madduppa HH, Wardiatno Y. 2020. Keragaman genetik mimi (Carcinoscorpius rotundicauda dan Tachypleus gigas) di perairan Demak, Madura dan Balikpapan berdasarkan penanda Random Amplified Polymorphic DNA. Jurnal Pengelolaan Sumber Daya Alam dan Lingkungan. 10(1): 124-137.

Beekey MA, Mattei JH, Pierce BJ. 2013. Horseshoe crab eggs: A rare resource for predators in Long Island Sound. J Exp Mar Bio Ecol. 439(1): 152-159.

Botton ML. 1984. The Importance of predation by horseshoe crabs, Limulus polyphemus, to an intertidal sand flat community. J Mar Res. 42(1): 139-161.

Botton ML. 2009. The ecological importance of horseshoe crabs in estuarine and coastal communities: a review and speculative summary. In: Tanacredi JT, Botton ML, Smith DR (Eds.). Biology and Conservation of Horseshoe Crabs. 45-63.

Botton ML, Haskin HH. 1984. Distribution and feeding of the horseshoe crab, Limulus Polyphemus, on the Continental Shelf of New Jersey. Fish Bull. 82(2): 383-389.

Botton ML, Ropes JW. 1989. Feeding ecology of horseshoe crabs on the continental shelf, New Jersey to North Carolina. Bull Mar Sci. 45(3): 637-47.

Carmichael RH, Rutecki D, Annet B, Gaines E, Valiela I. 2004. Position of horseshoe crabs in estuarine food webs: $\mathrm{N}$ and $\mathrm{C}$ stable isotopic study of foraging ranges and diet composition. $J$ Exp Mar Bio Ecol. 299(2): 231-253.

Cartwright-Taylor L, Von Bing Y, Chi HC, Tee LS. 2011. Distribution and abundance of horseshoe crabs Tachypleus gigas and Carcinoscorpius rotundicauda around the main island of Singapore. Aquat Biol. 13(2): 127-36.

Chabot CC, Watson III WH. 2010. Circatidal rhythms of locomotion in the American horseshoe crab Limulus polyphemus: underlying mechanisms and cues that influence them. Curr Zool. 56(5): 499-517.

Chatterji A, Mishra JK, Parulekar AH. 1992. Feeding behaviour and food selection in the horseshoe crab Tachypleus gigas (Muller). Hydrobiologia. 246(1): 41-48.

Colwell RK, Futuyma DJ. 1971. On the measurement of niche breadth and overlap. Ecology. 52(4): 567-576.

Eidman M, Mayunar, Redjeki S. 1997. Pematangan gonad mimi ranti, Carcinoscorpius rotundicauda (Latreille) dan mimi bulan Tachypleus gigas (Muller) dengan berbagai jenis pakan. Jurnal Ilmu-Ilmu Perairan dan Perikanan Indonesia. 5(1): 1-6. 
Erwyansyah, Wardiatno Y, Kurnia R, Butet NA. 2018. Kepastian taksonomi dan sebaran belangkas Tachypleus tridentatus Leach 1819 di Perairan Balikpapan Timur. Jurnal Ilmu dan Teknologi Kelautan Tropis. 10(3): 547-559.

Horn HS. 1966. Measurement of "overlap" in comparative ecological studies. Am Nat. 100(914): 419-24.

Hurlbert SH. 1978. The measurement of niche overlap and some relatives. Ecology. 59(1): 67-77.

Jawahir AN, Samsur M, Shabdin ML, Adha AK. 2017. Distribution of two species of Asian horseshoe crabs at west coast of Sarawak's Waters, East Malaysia. Egypt J Aquat Res. 43(2): 135-40.

John BA, Kamaruzzaman BY, Jalal KCA, Zaleha K. 2012a. Feeding ecology and food preference of Carcinoscorpius rotundicauda collected from the Pahang Nesting Ground. Sains Malays. 41(7): 855861.

John BA, Kamaruzzaman BY, Jalal KCA, Zaleha K. 2012b. TAL- a source of bacterial endotoxin detector in liquid biological samples. Int Food Res J. 19(2): 423-425.

John BA, Nelson BR, Sheikh HI, Cheung SG, Wardiatno Y, Dash BP, Tsuchiya K, Iwasaki Y, Pati S. 2018a. A review on fisheries and conservation status of Asian horseshoe crabs. Biodivers Conserv. 27(14): 3573-3598.

John BA, Nelson BR, Sheikh HI, Cheung SG, Wardiatno Y, Dash BP, Tsuchiya K, Iwasaki Y, Pati S. 2018 b. Correction to: A review on fisheries and conservation status of Asian horseshoe crabs. Biodivers Conserv. 27(14): 3845.

Kwan BK, Cheung SG, Shin PK. 2015. A dual stable isotope study for diet composition of juvenile Chinese horseshoe crab Tachypleus tridentatus (Xiphosura) on a seagrass-covered intertidal mudflat. Mar Biol. 162(5): 1137-43.

Levins R. 1968. Evolution in changing environments. New Jersey (US): Princeton University Press.

Mashar A, Butet NA, Juliandi B, Qonita Y, Hakim AA, Wardiatno Y. 2017. Biodiversity and distribution of horseshoe crabs in Northern Coast of Java and Southern Coast of Madura. IOF Conf. Series: Earth and Environmental Science. 54: 012076.

Natarajan AV, Jhingran AG. 1961. Index of preponderance - a method of grading the food elements in the stomach analysis of fishes. Indian J Fish. 8(1): 54-49.

Nikolsky GV. 1963. The Ecology of Fishies. London (GB): Academic Press.

Novakowski GC, Hahn NS, Fugi R. 2008. Diet seasonality and food overlap of the fish assemblage in a pantanal pond. Neotrop Ichthyol. 6(4): 567-76.

Novitsky TJ. 1994. Limulus amebocyte lysate (LAL) detection of endotoxin of human blood. J Endotoxin Res. 1(4): 253-263.

Nugroho TS, Fahruddin A, Yulianda F, Bengen DG. 2018. Analisis kesesuaian lahan dan daya dukung ekowisata mangrove di Kawasan Mangrove Muara Kubu, Kalimantan Barat. Jurnal Pengelolaan Sumber Daya Alam dan Lingkungan. 9(2): 483-497.

Papacostas KJ, Freestone AL. 2016. Latitudinal gradient in niche breadth of brachyuran crabs. Global Ecology and Biogeography. 25(2): 207-17.

Pianka ER. 1973. The structure of lizard communities. Annu Rev Ecol Syst. 4: 53-74.

Razak MRM, Kassim Z, Sabuti AA, Ismail A. 2017. Feeding ecology and food preferences of Cherok Paloh, Pahang Horseshoe Crab, Tachypleus gigas. Mal. J. Fund. Appl. Sci. 3(3): 198-202.

Samidurai K, Saravanakumar A, Kathiresan K. 2012. Spatial and temporal distribution of macrobenthos in different mangrove ecosystems of Tamil Nadu Coast, India. Environ Monit Assess. 184(7): 4079-4096.

Sekiguchi K, Shuster CN. 2009. Limits on the global distribution of horseshoe crabs (Limulacea): lessons learned from two lifetimes of observations: Asia and America. In: Tanacredi JT, Botton ML, Smith DR (Eds.). Biology and Conservation of Horseshoe Crabs. 5-24.

Shin PKS, Li HY, Cheung SG. 2009. Horseshoe crabs in Hong Kong: Current population status and human exploitation. In: Tanacredi JT, Botton ML, Smith DR (Eds.). Biology and Conservation of Horseshoe Crabs. 347-360. 
Smith DR. 2007. Effect of horseshoe crab spawning density on nest disturbance and exhumation of eggs: a simulation study. Estuaries. 30(2): 287-295.

Smith MD, Schrank HE, Brockmann HJ. 2013. Measuring the costs of alternative reproductive tactics in horseshoe crabs, Limulus polyphemus. Anim Behav. 85(1): 165-73.

Squires HJ, Dawe EG. 2003. Stomach contents of snow crab (Chionoecetes opilio, Decapoda, Brachyura) from the Northeast Newfoundland Shelf. J Northwest Atl Fish Sci. 32: 27-38.

Tsuchiya K. 2009. The history of horseshoe crab research and conservation in Japan. In: Tanacredi JT, Botton ML, Smith DR (Eds.). Biology and Conservation of Horseshoe Crabs. 559-570.

Walls EA, Berkson J, Smith SA. 2002. The Horseshoe crab, Limulus polyphemus: 200 million years of existence, 100 years of study. Rev Fish Sci. 10(1): 39-73.

Wijaya D, Nurfiarini A, Nastiti AS, Riswanto. 2017. Kebiasaan makanan, luas dan tumpang tindih relung beberapa jenis lobster di Teluk Prigi Kabupaten Trenggalek. Bawal. 9(3): 153-161.

Zaleha K, John BA, Atika HE, Kamaruzzaman BY, Jalal KC. 2012. Spawning and nesting behaviour of Tachypleus gigas along the East Coast of Peninsular Malaysia. Int. J. Biol. 4(2): 102-11.

Zhou H, Morton B. 2004. The diets of juvenile horseshoe crabs, Tachypleus tridentatus and Carcinoscorpius rotundicauda (Xiphosura), from nursery beaches proposed for conservation in Hongkong. J Nat Hist. 38(15): 1915-1925.

Zhu G, Yuan X, Fan J. 2020. Insight into intraspecific niche divergence and conservatism in American horseshoe crabs (Limulus polyphemus). Glob Ecol Conserv. 22: 1-9. 